\title{
Pelatihan Dan Pendampingan Manajemen Usaha Wanita Pengrajin Kemplang Panggang Di Kota Palembang
}

\author{
Yusleli Herawati ${ }^{1}$ Yahya $^{2}$, Abdul Hamid ${ }^{3}$ \\ Politeknik Negeri Sriwijaya \\ Korespondensi: yusleliherawati@gmail.com
}

Diserahkan: 15 Agustus 2018, Direvisi: 23 Agustus 2018, Diterima: 8 September 2018

\begin{abstract}
abstrak
Kegiatan pengabdian masyarakat ini meliputi pelatihan, pembinaan, dan pendampingan terhadap Usaha Wanita Pengrajin Kemplang Panggang di Kelurahan Pipa Reja Kota Palembang dengan melibatkan 2 (dua) orang mitra. Kegiatan ini bertujuan untuk memberikan pemahaman, pembekalan, dan pelatihan kepada pengrajin kemplang panggang dalam aspek produksi, pemasaran, pembiayaan, dan adminitrasi agar usaha kemplang panggang dapat lebih berkembang. Berdasarkan hasil pengamatan awal dapat diidentifikasi beberapa permasalahan antara lain: 1) Jumlah produksi yang tidak stabil, 2) Produk yang kurang higienis, 3) Peralatan kerja kurang memadai, 4) Keterbatasan modal kerja, 5) Belum memiliki identitas promosi, dan 6) Belum menerapkan pembukuan usaha.

Metode pelaksanaan dalam kegiatan ini terbagi dalam beberapa tahapan yaitu: 1) Tahap persiapan dan perencanaan, 2) Tahap implementasi kegiatan, 3) Tahap evaluasi dan monitoring, dan 4) Tahap refleksi. Dari hasil kegiatan tampak bahwa terjadi peningkatan daya saing pengrajin kemplang panggang dan penerapan IPTEK, kemampuan pembuatan laporan keuangan usaha, dan pemanfaatan sosial media untuk pemasaran online. Selain itu, mitra juga sudah mampu melakukan manajemen usaha dan membuat proposal kredit bank dan pembentukan paguyuban usaha.
\end{abstract}

Kata kunci: Kemplang, Pipa Reja, Manajemen Usaha, Pengabdian masyarakat

\section{abstract}

This community service activity includes training, coaching, and assistance to the Women's Business of Baked Kemplang Craftsmen in the Pipa Reja Village in Palembang City by involving 2 (two) partners. This activity aims to provide understanding, debriefing, and training to baked bakers in the aspects of production, marketing, financing, and administration so that the bakery business can be more developed. Based on the initial observations, several problems can be identified, including: 1) Unstable amount of production, 2) Less hygienic products, 3) Inadequate work equipment, 4) Limited working capital, 5) Not having a promotional identity, and 6) Not yet apply business bookkeeping. The implementation method in this activity is divided into several stages, namely: 1) Preparation and planning stage, 2) Phase of implementation of activities, 3) Phase of evaluation and monitoring, and 4) Phase of reflection. From the results of the activities, it appears that there is an increase in the competitiveness of the bakers and the application of science and technology, the ability to make business financial reports, and the use of social media for online marketing. In addition, partners have also been able to conduct business management and make bank credit proposals and the formation of business associations.

Keywords: Kemplang, Pipa Reja, Business Management, Community Service

\section{A. PENDAHULUAN}

\section{Latar Belakang}

Program pembinaan dan pemberdayaan terhadap pelaku Usaha Kecil Mikro dan Menengah (UMKM) sudah banyak dilakukan baik oleh pemerintah pusat dan daerah maupun pihak swasta dan perguruan tinggi. Namun pembinaan dan pemberdayaan tersebut belum memadai dan belum sesuai dengan kebutuhan atau permasalahan yang dihadapi pelaku UMK. Menurut Kuncoro (2000) walaupun sudah banyak pembinaan dan pemberdayaan terhadap usaha kecil (termasuk mikro), namum belum memberikan hasil yang maksimal. Hal ini disebabkan oleh pembinaan dan pemberdayaan yang dilakukan oleh berbagai instansi masih bersifat tumpang tindih dan dilakukan sendiri- 
sendiri tanpa terkoordinasi dengan baik. Pelaku UMK terkesan hanya sebagai obyek dan diperlakukan secara terkotak-kotak, sedangkan institusi Pembina hanya mementingkan dan mengejar target dan sasarannya masing-masing.

Program pembinaan dan pemberdayaan telah banyak dilakukan baik oleh pemerintah pusat dan daerah maupun pihak swasta dan perguruan tinggi, kenyataan di lapangan masih banyak pelaku UMK yang belum sempat tersentuh program pembinaan dan pemberdayaan serupa. Hal ini disebabkan masih ada pelaku UMK yang tidak terdata pada Dinas Koperasi dan UKM. Salah satunya adalah usaha mikro yang ada di sepanjang jalan Pipa Kecamatan Pipa Reja yaitu Usaha Wanita Pengrajin Kemplang Panggang di Jalan Pipa Kecamatan Pipa Reja Kecamatan Kemuning Palembang. Usaha mikro ini telah ada sejak lama di Jalan Pipa, lokasi yang strategis, dan cukup terkenal sebagai pusat penjualan kemplang panggang serta terdapat banyak pengusaha kemplang panggang di kiri dan kanan sepanjang Jalan Pipa tersebut dengan kondisi lalu lintasnya yang ramai. Calon pembeli yang ingin membeli kemplang panggang khas ini cukup datang ke Jalan Pipa.

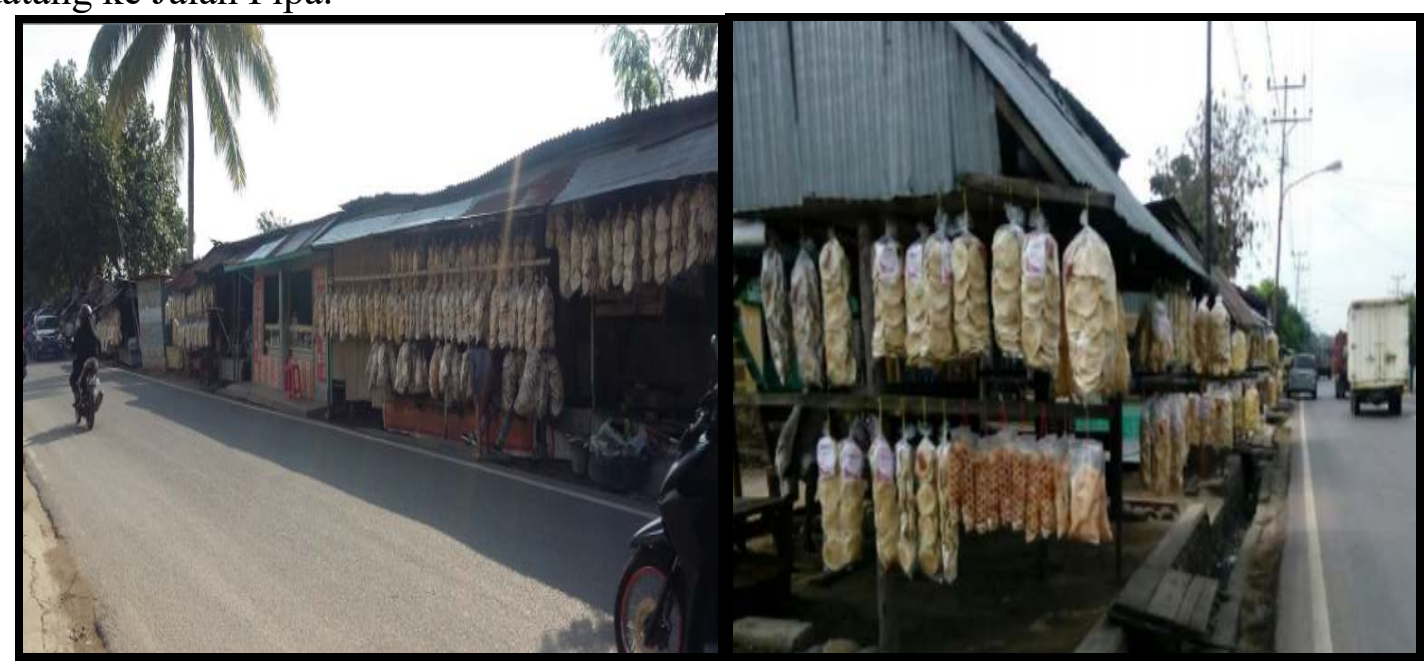

Gambar 1: Lokasi Penjualan Kemplang Panggang Jalan Pipa Reja

Semua pengrajin kemplang panggang di sepanjang kanan dan kiri Jalan Pipa adalah wanita. Usaha Wanita Pengrajin Kemplang Panggang di Kelurahan Pipa Reja Palembang merupakan usaha wanita yang memperoduksi dan menjual kemplang panggang dalam skala mikro.

\section{PROFIL MITRA}

Mitra yang akan dilibatkan dalam kegiatan ini adalah Usaha Kemplang Panggang Leli (Mitra I) dan Usaha Kemplang Panggang Sawiyah (Mitra II). Kedua mitra sudah memulai usahanya sejak tahun 2011. Bahan baku kemplang panggang adalah Ikan Tenggiri (Tenggiri Papan, Tenggiri, atau Gabus) dan udang. Ikan dan udang yang digunakan dalam pembuatan kemplang panggang hanya sedikit, bahan lainnya adalah sagu, garam dan telur. Jadi jenis ikan yang digunakan dan semakin banyak ikan yang digunakan dalam adonan kemplang dan dapat mempengaruhi harga jual kemplang panggang tersebut. Jumlah pekerja dalam usaha mikro ini tidak ada, produksi selain mitra dibantu oleh anggota keluarga. Untuk Produksi kemplang panggang biasa dari Tenggiri Papan membutuhkan modal rata-rata sebesar Rp. 160 ribu sekali produksi per hari, dapat diproduksi berkisar 25-30 kantong kemplang panggang (isi 20 keping), sehingga dalam sebulan diproduksi rata-rata $120 \mathrm{~kg}$ bahan baku yang akan 
menghasilkan 900 kantong kemplang panggang (isi 20 keping) siap jual. Berikut ilustrasi biaya rata-rata produksi, penjualan, dan keuntungan per hari :

Tabel 1. Biaya Rata-Rata Produksi, Penjualan, dan Keuntungan Produksi Kemplang Panggang

\begin{tabular}{|l|lr|}
\hline Bahan Baku (4 kg x Rp. 30.000) & $\mathrm{Rp}$ & 120.000 \\
Plastik (1 bal x Rp. 10.000) & $\mathrm{Rp}$ & 10.000 \\
Arang (1 x Rp 10.000) & $\mathrm{Rp}$ & 10.000 \\
Cabai kemplang (1 x Rp 5.000) & $\mathrm{Rp}$ & 5.000 \\
Kantong Plastik (1 pack x Rp 25.000) & $\mathrm{Rp}$ & 25.000 \\
Total Biaya bahan, arang, dan kantong & $\mathrm{Rp}$ & 170.000 \\
Penjualan rata-rata (30 kantong. @ 20 & $\mathrm{Rp}$ & 450.000 \\
keping kemplang panggang, 1 kantong= Rp & & \\
15.000) & & \\
\hline Keuntungan per hari & $\mathrm{Rp}$ & 280.000 \\
\hline
\end{tabular}

Sumber: Hasil wawancara lapangan

Harga jual per kantong kemplang panggang (sekantong isi 20 keping) berkisar Rp. 15.000 - Rp. 25.000 tergantung jenis kemplang panggang (ikan atau dari udang, dengan keuntungan rata-rata $\mathrm{Rp} 290$ ribu ketika musim sepi dan keuntungan sampai $\mathrm{Rp}$ 750 ribu (terjual 50 kantong) dalam sehari jika ramai terutama saat menjelang lebaran dan tahun baru.

Tabel 2. Harga Kemplang Panggang

\begin{tabular}{|l|l|l|}
\hline No. & Jenis Kemplang Panggang & $\begin{array}{l}\text { Harga Jual Kantong } \\
\text { per kantong (isi 20 } \\
\text { keping) }\end{array}$ \\
\hline 1 & Kemplang panggang udang & $\mathrm{Rp} \mathrm{25.000}$ \\
\hline 2 & Kemplang panggang udang super & $\mathrm{Rp} \mathrm{40.000}$ \\
\hline 3 & Kemplang panggang biasa (Tenggiri papan) & $\mathrm{Rp} \mathrm{15.000}$ \\
\hline 4 & Kemplang panggang super (Tenggiri/Gabus) & $\mathrm{Rp} \mathrm{20.000}$ \\
\hline
\end{tabular}

Sumber: Hasil wawancara lapangan

Dalam menjalankan aktivitasnya kedua mitra mengalami permasalahan yang sama. Secara umum permasalahan yang dihadapi dan disepakati sebagai prioritas masalah yang harus diatasi antara lain adalah tidak menentunya jumlah produksi, rendahnya hiegenitas kemplang panggang siap jual, tempat produksi yang kurang memadai, belum ada kemasan dan merek sebagai pengenal, keterbatasan modal, dan belum pernah memperoleh pembinaan sama sekali. Menurut Hasan (2003) mengemukakan masalah yang dihadapi industri kecil merupakan masalah klasik sebagai berikut: 1) Masalah kurangnya keterampilan dan jangkauan menggunakan kesempatan yang meliputi kewiraswastaan, pengelolaan usaha dan organisasi, 2) Masalah kurangnya pengetahuan pemasaran dan sempitnya daerah pemasaran, 3) Langkanya modal, 4) Masalah teknis dan teknologi, yang meliputi keterampilan dan pengetahuan produksi, kualitas, pengembangan dan peragaman produk. Melalui PKM Ristekdikti ini 
diharapkan permasalahan yang menjadi prioritas tersebut dapat diselesaikan dengan menawarkan solusi yang bermanfaat bagi mitra.

Berdasarkan hasil kunjungan lapangan, wawancara, dan pengamatan terhadap Usaha Wanita Pengrajin Kemplang Panggang di sepanjang Jalan Pipa Kecamatan Pipa Reja Kelurahan Kemuning Palembang, dapat diidentifikasi beberapa permasalahan yakni :

1. Produksi kemplang panggang tidak menentu disebabkan ketergantungan pada kondisi musim atau keadaan cuaca. Jika kondisi panas maka proses pengeringan kemplang dapat lebih cepat. Saat ini produksi berfluktuasi antara 25 - 30 kantong (isi 20 keping) per hari.

2. Produksi dan penjualan dilakukan di pinggir jalan, sehingga higienitas hasil produksi kemplang panggang relatif rendah. Kemplang panggang siap jual hanya dijajakan dalam kantong-kantong plastik dan selama pemanggangan, kemplang yang telah selesai di panggang dibiarkan terbuka.

3. Belum memiliki kantong plastik berlogo dan hanya menggunakan kantong plastik yang tidak ada identitas usaha.

4. Tidak memiliki merek (brand) atau identitas, sehingga pelanggan sulit mengenali nama dan pemilik usaha. Dengan kata lain belum ada aktivitas promosi sama sekali.

5. Tungku pemanggangan kemplang masih sangat sederhana, sehingga kualitas dan tampilan kemplang panggang relatif kurang baik. Kemplang panggang terlihat bintik bintik hitam bekas arang dan kurang menarik.

6. Cabai kemplang panggang hanya dibungkus kantong plastik biasa, tidak higienis, dan dengan kualitas yang belum baik.

7. Hanya mengandalkan modal sendiri dan terbatasnya modal kerja, sehingga produksi belum optimal. Belum adanya kerjasama (sinergi) antar sesama pengrajin kemplang panggang di area Jalan Pipa baik dalam pemasaran maupun penggalangan modal kerja.

8. Belum adanya pembukuan usaha yang dilakukan oleh mitra.

\section{B. TINJAUAN PUSTAKA}

Kegiatan Pengabdian Kepada Masyarakat (PKM) yang dilakukan oleh penulis adalah salah satu bentuk penerapn dari Tri Dharma Dosen yaitu pengabdian kepada masyarakat dengan sumber pendanaan dari kemetrian riset dan teknologi (Kemenristekdikti). Kegiatan ini menitikberatkan kepada pembinaan kepada kelompok masyarakat, terutama yang memberi manfaat ekonomi kepada kelompok masyarakat wirausaha. Hal ini sejalan dengan manfaat wirausaha antara lain: 1) Membuka lapangan kerja baru, 2) Sebagai generator pembangunan lingkungan, 3) Sebagai contoh pribadi unggul, terpuji, jujur, berani dan tidak merugikan orang lain, 4) Menghormati hukum dan peraturan yang berlaku, 5) Mendidik karyawan jadi orang mandiri, disiplin, jujur dan tekun, dan 6) Memelihara keserasian lingkungan, baik dalam pergaulan maupun dalam kepemimpinan (Alfianto, E. A., Sos, S., \& AB, M. 2012). 


\section{Metode Pelaksanaan}

Empat bentuk kerja utama yang dilakukan, mulai dari tahap persiapan dan perencanaan, tahap implementasi kegiatan, tahap evaluasi dan monitoring, dan tahap refleksi. Prosedur kerja kegiatan ini ditunjukkan pada gambar 1.

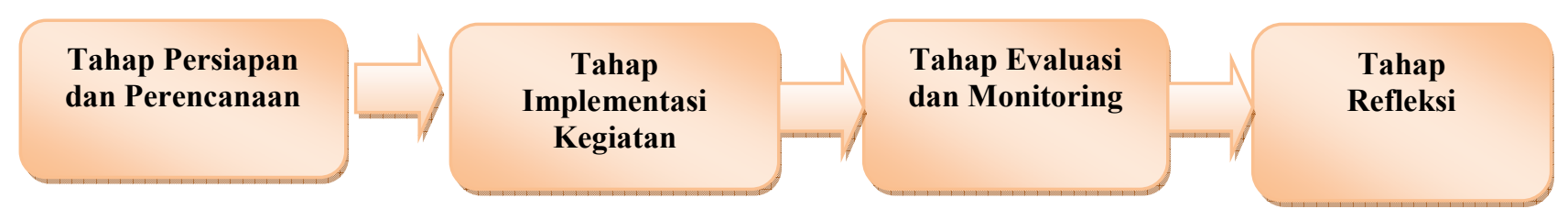

Gambar 2. Prosedur Kerja Program PKM

Pelaksanaan kegiatan PKM ini dilakukan dengan metode partisipatif dimana mitra sasaran ikut terlibat langsung baik dalam FGD (Focus Group Discussion), wawancara, dan menentukan keputusan tindakan. Kegiatan PKM terdiri dari 4 tahapan sebagai berikut :

\section{Tahap Persiapan dan Perencanaan}

Pada tahap ini tim pelaksana melakukan beberapa persiapan dan perencanaan antara lain :

a. Sosialisasi Kegiatan PKM (Pemaparan oleh Tim Pelaksana dan FGD dengan Mitra I dan Mitra II). Pada tahap ini akan dijelaskan maksud dan tujuan, metode dan teknis pelaksanaan PKM, serta akan disepakati permasalahan yang menjadi prioritas untuk dicarikan solusinya.

b. Penyusunan Program Kegiatan (FGD dengan Mitra I dan Mitra II) Menentukan bentuk, waktu dan tempat pelaksanaan kegiatan. Program kegiatan terdiri dari pelatihan pemasaran dan promosi usaha, pelatihan tentang permodalan usaha dan pembuatan proposal, pelatihan pembentukan paguyuban, pelatihan pembukuan usaha, dan pembuatan alat pemajangan produk (etalase), tungku pemanggangan, dan pembotolan cabai kemplang panggang. Dalam hal ini perlu didisain sedemikian rupa sehingga pemanggangan dapat efektif namun hasilnya lebih baik.

\section{Tahap Implementasi Kegiatan}

Pada tahap ini Tim pelaksana akan memulai kegiatan sesuai dengan jadwal yang sudah ditentukan dan disepakati bersama dengan mitra.

3. Tahap Evaluasi dan Monitoring

Pada tahap ini pelaksanaan kegiatan di-monitoring oleh tim sendiri dan melihat apa saja kendala dan masalah yang muncul di lapangan. Kemudian dilakukan evaluasi apabila memang muncul kendala dan masalah untuk selanjutnya dicarikan solusi agar kegiatan tetap berlangsung dengan baik sesuai yang diharapkan.

4. Tahap Refleksi

Setelah semua kegiatan terlaksana sesuai jadwal, maka dilakukan refleksi terhadap pelaksanaan kegiatan tersebut, dimana mitra dapat mengungkapkan manfaat maupun dampak yang muncul setelah dilakukan pelatihan dan pembinaan. Hal ini diperlukan sebagai masukan bagi pelaksanaan kegiatan serupa di masa datang.

Pengusul dan kedua mitra, masing-masing memiliki peran penting dalam kesuksesan kegiatan PKM ini. Pengusul berperan dalam menyediakan hal-hal yang berkaitan dengan fasilitas teknologi, seperti: alat pengering kemplang, tempat pemajangan (etalase) berbentuk gerobak yang tertutup kaca, tungku pemanggangan, 
desain kartu nama, dan desain kantong plastik berlogo. Sedangkan mitra berperan aktif dalam memberikan masukkan mengenai penyusunan program kegiatan, pembuatan jadwal kegiatan, desain kemasan yang diinginkan, dan kegiatan-kegiatan Focus Group Discussion (FGD)

\section{Hasil dan Pembahasan}

Tahap-tahapan kegiatan pelatihan dan pendampingan telah dilakukan terhadap Mitra I dan Mitra I. Pelatihan dan pendampingan pertama yang dilakukan terhadap Mitra I dan Mitra II adalah Pelatihan pemasaran dan promosi online yang dilaksanakan tanggal 30/03/2018 dan 31/03/2018. Hasil adalah kantong plastik bermerek untuk mitra I dan mitra II yang digunakan dalam pembungkusan kemplang panggang. Berikut ini adalah beberapa hasil kegiatan pelatihan dan pendampingan yang dilakukan pada mitra I dan mitra II.
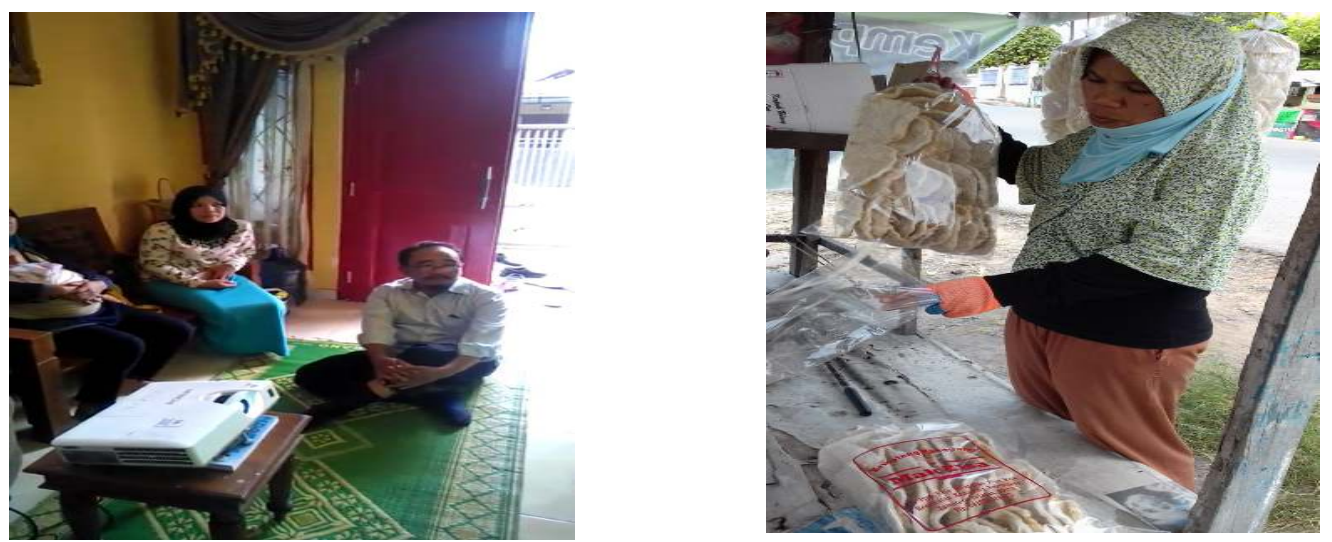

Gambar 2. Kegiatan-kegiatan Pelatihan dan Pendampingan oleh Tim Pelaksana


Gambar 3. Logo Merek Mitra yang tertera di Kantong Pembungkus 
Setelah kegiatan pelatihan Pemasaran dan Promosi Online, selanjutnya diadakan Pelatihan dan pendampingan manajemen Permodalan Usaha untuk mitra I dan II yang dilaksanakan tanggal 6/04/2018 dan 7/04/2018. Selanjutnya diadakan Pelatihan dan pendampingan Pembuatan Proposal Kedit untuk mitra I dan II yang dilaksanakan tanggal 13/04/2018 dan 14/04/2018. Pelatihan pembentukan paguyuban untuk kedua mitra dilaksanakan tanggal 19/04/2018 dan 20/04/2018, yang hasilnya adalah terbentuk satu paguyuban sesama pengrajin kemplang panggang di Jalan Pipa Reja, yang berjumlah 9 orang. Fungsi paguyuban atau komunitas ini adalah : menjaga harga pasaran kemplang panggang di lokasi Jalan Pipa Reja, menjadi wadah penyaluran aspirasi bersama, membantu mengatasi jika ada masalah/kendala usaha, dan kegiatan positif lainnya. Pelatihan dan pendampingan selanjutnya adalah pembukuan usaha untuk kedua mitra dilaksanakan tanggal21/04/2018 dan 22/04/2018. Tanggal 5 Mei 2018, tim pelaksana PKM menyerahkan tempat pemajangan produk (etalase) ke mitra I dan II. Selanjutnya tanggal 12 Mei 2018 dilaksanakan penyerahan tungku pemanggangan kemplang dan melakukan sekaligus melakukan pelatihan pembotolan cabai kemplang panggang ke mitra I dan II.

Tahap selanjutnya adalah Monitoring dan Evaluasi, pelaksanaan kegiatan dimonitoring oleh tim sendiri dan melihat apa saja kendala dan masalah yang muncul di lapangan. Kemudian dilakukan evaluasi apabila memang muncul kendala dan masalah untuk selanjutnya dicarikan solusi agar kegiatan tetap berlangsung dengan baik sesuai yang diharapkan. Setelah semua kegiatan terlaksana sesuai jadwal, maka dilakukan refleksi terhadap pelaksanaan kegiatan tersebut, dimana mitra dapat mengungkapkan manfaat maupun dampak yang muncul setelah dilakukan pelatihan dan pembinaan. Hal ini diperlukan sebagai masukan bagi pelaksanaan kegiatan serupa di masa datang. Tahap refleksi ini dinyatakan dalam bentuk pemetaan melalui analisis SWOT (Strengths, Weaknesses, Opportunities, Threats) pada mitra I dan mitra II. Hasil SWOT ini dihubungkan juga dengan hasil kuesioner yang diberikan kepada pelaku/pemilik usaha.
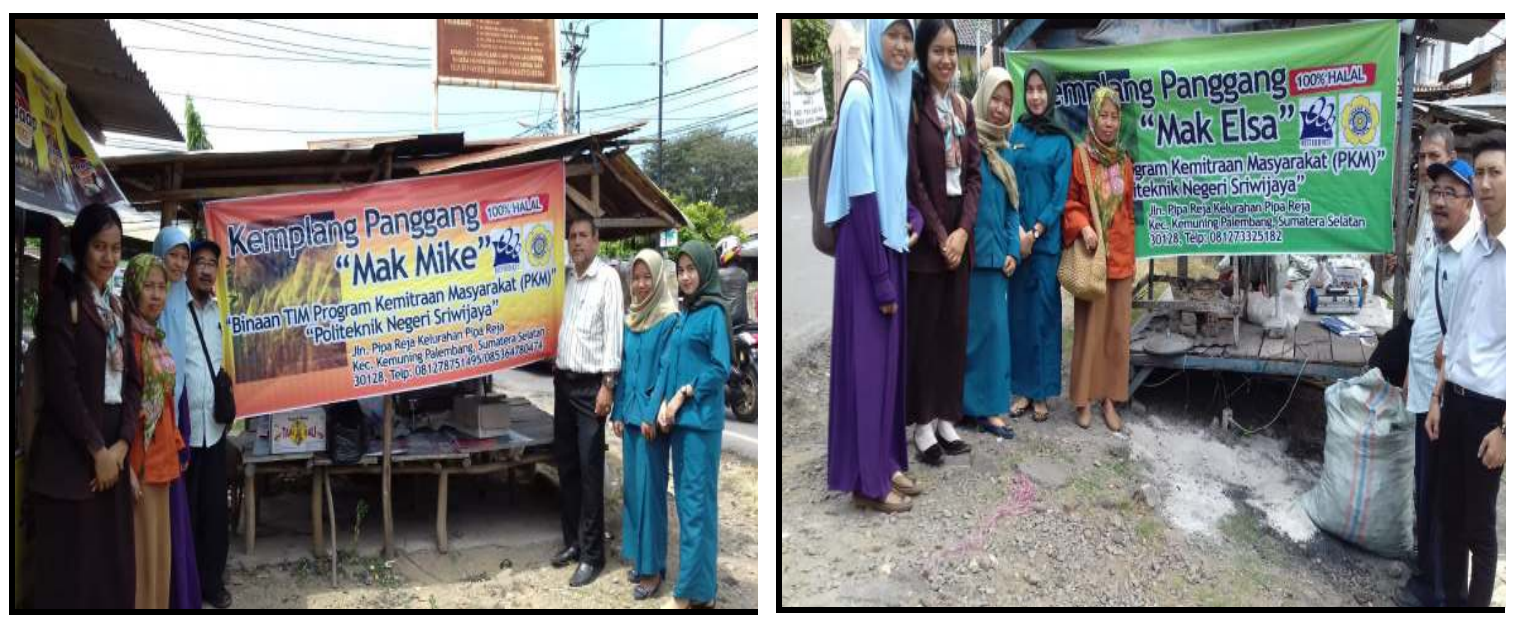

\section{Gambar 4. Perkembangan Usaha Mitra I dan Mitra II}

Hasil dari kegiatan pelatihan dan pendampingan yang dilakukan selama 8 bulan didapatkan berdasarkan hasil kuesioner yang diberikan kepada pihak mitra tersebut adalah terjadi peningkatan daya saing usaha pada mitra I dan mitra II dengan capaian sebesar $70 \%$. Tempat usaha masing-masing mitra terlihat telah lebih baik dengan tungku pemanggangan yang lebih baik dan rapi, tersedia etalase kaca sebagai tempat 
penyimpanan dan pajangan kemplang panggang yang akan dijual sehingga terhindar dari debu dan kotoran, cabai kemplang lebih higienis karena telah dilakukan pembotolan, serta bungkus kemplang yang telah tersedia merek usaha serta terbentuk paguyuban/komunitas sesama pengrajin kemplang panggang yang berlokasi di Jalan Pipa Reja. Disamping itu, terjadi peningkatan penerapan IPTEK, dimana pengetahuan dan skill pelaku usaha (mitra I dan mitra II) telah lebih baik karena telah memiliki kemampuan pemasaran secara online dengan memanfaatkan sosial media yang ada khusus facebook dan whats app. Begitu pula halnya dengan kemampuan penyajian laporan keuangan usaha telah lebih baik dari sebelumnya. Peningkatan kemampuan manajemen usaha mitra I dan mitra II dengan capaian sebesar $65 \%$. Hal ini ditunjukkan melalui peningkatan pengetahuan dan kemampuan masing-masing mitra dalam pengelolaan manajemen usaha dan kemampuan membuat proposal pengajuan kredit bank.

\section{E. Penutup}

Dari hasil pelatihan dan pendampingan kegiatan PKM Usaha Wanita Pengrajin Kemplang Panggang Jalan Pipa Kelurahan Pipa Reja Kota Palembang diketahui bahwa mitra mengalami peningkatan daya saing pengrajin kemplang panggang (skill manajemen usaha dan skill pemasaran sebesar $70 \%$ dari biasanya. Peningkatan juga terjadi pada penerapan teknologi yaitu pemanfaatan alat, peningkatan kemampuan pembuatan laporan keuangan usaha, dan pemanfaatan sosial media untuk pemasaran online dengan capaian sebesar $75 \%$. Mitra usaha juga sudah mengalami peningkatan kemampuan manajemen usaha pengrajin kemplang panggang dan mampu membuat proposal kredit bank dan pembentukan paguyuban usaha dengan capaian sebesar $65 \%$. Sebagai luaran tambahan dari kegiatan ini, penulis juga telah membuat modul pelatihan, draft Buku ber ISBN, Publikasi ilmiah pada Jurnal ber ISSN/Prosiding, dan Publikasi pada media masa cetak/online/repositori di Politeknik Negeri Sriwijaya.

\section{DAFTAR PUSTAKA}

Hasan, Bachtiar. 2003. Manajemen Industri. Bandung: Ramadhan Citra Grafika. Hartarto, Airlangga dan Muhajir. 2013., "Pemberdayaan Koperasi dan UMKM Dalam Rangka Peningkatan Perekonomian Masyarakat (www.depkop.go.id/phocadownload/Rakernas_2013/komisi\%20vi\%20dpr-ri.pdf)

Kasih, Yulizar dan Rini Aprilia. 2013.'The Competitiveness of Indonesian MicroSmall-Medium Enterprises (MSMEs) Facing ASEAN Economic Community (AEC) in 2015", Proceeding, ICEISM 2014, p.159.

Kuncoro, Mudrajad (2013), "Usaha Kecil di Indonesia : Profil, Masalah, dan Strategi Pengembangan," www.mudrajad.com (diakses 26/12/2014).

Alfianto, E. A., Sos, S., \& AB, M. (2012). Kewirausahaan: Sebuah Kajian Pengabdian Kepada Masyarakat. HERITAGE, 1(2), 33-42. 